\title{
ŽENA OD ANTIČKOG IMPERATIVA „SKRBI ZA SEBE“ DO ETIČKOG IMPERATIVA „BRIGE ZA DRUGOGA“: FEMINISTIČKI I KRŠĆANSKI POGLED
}

\author{
Marijo Volarević
}

Sveučilište u Splitu

Katolički bogoslovni fakultet

UDK: 347.163“652“

305-055.2

mvolarevic@kbf-st.hr

27:141.72

https://doi.org/10.34075/cs.56.3.10

Pregledni znanstveni rad

Rad zaprimljen 5/2021

\section{Sažetak}

Etičkim propitivanjem 'skrbi za sebe' $i$ ‘brizi za drugog' autor se bavi pitanjem statusa žene, njezine važnosti i njezina etičkog doprinosa društvu. U prvom dijelu se, polazeći od antičkog imperativa sskrbi za sebe', progovara o povijesnoj podređenosti žene i položaju žene $u$ društvu, koji jasno pokazuje kako je antički imperativ 'skrbi za sebe' za žene vrijedio $u$ onoj mjeri u kojoj su im to muškarci dopuštali, budući da je u patrijarhalnom društvu koji su kreirali muškarci čitava društvena moć bila u njihovim rukama. Tek nastankom feminizma $i$ emancipacijom žena u društvu, o čemu se progovara u drugom djelu rada, žena dobiva vlastiti prostor da može 'skrbiti se za sebe'. U tom se kontekstu zapravo tek tada antički imperativ 'skrbi za sebe'pokazuje kao etički imperativ za svakog čovjeka, podjednako za muškarca i ženu, odnosno žena postaje ravnopravan partner muškarcu, što joj pripada po dostojanstuu ljudske osobe - biti čovjek.

U trećem dijelu rada progovara se o etičkom imperativu koji se veže za ženu i njezina prava te o njezinoj različitosti u odnosu na muškarca. Ta različitost očituje se i na etičkom području, te je jedno od temeljnih pitanja ono kakvu etiku žene zastupaju i ima li razlike između etike muškarca i žene. Veže li se ta etika uz feminističku etiku ili uz etiku utemeljenu na specifičnosti biti žena temeljni je cilj istraživanja ovog rada. U tom kontekstu možemo reći da jedna od etika koja se temelji na dostojanstuu biti žena jest retika brige za drugoga', o čemu se progovara u četvrtom dijelu rada. Ta 'etika brige za drugog' dostaje slična etici koja proizlazi iz novog feminizma Ivana Pavla II., o čemu autor progovara $u$ petom dijelu rada, gdje se zaključuje da bi zadaća novog feminizma bila kreiranje 'dvoglasne kulture', u kojoj 
žena i muškarac stoje kao jednakopravni partneri u svojoj istovjetnosti, ali i različitosti, doživljavajući jedno drugo kao dar i obogaćenje.

Ključne riječi: antika, 'skrbi za sebe', žena, muškarac, feministička etika, etika brige za drugoga, feminizam, novi feminizam.

\section{UvOD}

Počevši već od antike i glasovite Aristotelove definicije žene (Femina est mas occasionatus) kao nepotpunog muškaraca, žena je sve do modernog doba bila građanka drugog reda. Zbog svog spola smatrala se fizički, moralno i intelektualno inferiornijom naspram muškarcu, koji je u antici bio nositelj svih moralnih vrlina. Stoga smatram opravdanim postaviti pitanje je li antički etički imperativ ‘skrbi za sebe` uključivao i ženu. Opravdanost pitanja zorno nam pokazuje i primjer razgovora između Sokrata i Alkibijada. Sokrat kao mudar čovjek ima zadaću pozvati mladiće da se u prvom redu skrbe za sebe, za svoju dušu, poradi jačanja intelektualnih i moralnih vrlina. Tako Sokrat s jedne strane slijedi božanski zahtjev, a s druge služi polisu; učeći građane da se brinu za sebe, za vlastiti imetak, uči ih i odgovornosti prema polisu. Sokrat daje do znanja Alkibijadu kako mladići moraju naučiti sami sebe voditi prije nego što postanu upraviteljima polisa i voditeljima njegovih stanovnika. U dijalogu između Alkibijada i Sokrata ističe se kako Alkibijad, prema Sokratu, još nema sposobnost i umijeće vladanja gradom državom jer ne zna što to znači brinuti se o sebi. Sokrat mu želi reći da ce tek onda kada bude mogao upravljati svojom dušom, biti sposoban upravljati i gradom. ${ }^{1}$

Ovdje dolazimo do činjenice da žena u antici upravo zbog svoje moralne manjkavosti, kako se smatralo u to vrijeme, i nemogućnosti ostvarenja moralnih vrlina, nije mogla aktivno sudjelovati u obnašanju političkih poslova. Zbog toga možemo slobodno reći da je antički imperativ 'skrbi za sebe` za ženu oživio tek u moderno doba, pojavom emancipacijskih ženskih pokreta i nastankom feminizma. Dugogodišnjom borbom za svoja prava žena je uspjela doći do položaja da se može «skrbiti se za sebe», ali je zadnjih pola stoljeća, osobito među radikalnijim feminističkim skupinama, zaboravila na brigu i skrb za drugog, pa čak i unutar samih feminističkih pravaca. To su primijetile pojedine feministkinje 80-ih godina 20. stoljeća, poput Carol Gilligan, Nel Noddings, Sare Rudic, koje sve više stavljaju naglasak na retiku brige za drugogar. Danas je ovaj vid etičkog imperativa

1 Franjo MIJATOVIĆ, Moralni subjekt bez (vanjskih) ograničavanja. Etički elementi u filozofiji Michela Foucaulta, Bogoslovka smotra, 88 (2018.) 4, 947. 
gotovo posve zaboravljen $\mathrm{u}$ feminističkim krugovima i vrlo se malo spominje. Važno je napomenuti da je ova etika ‘brige za drugoga` dosta bliska i kršćanskim promišljanjima. Njezina sličnost osobito se može vidjeti u 'novom feminizmu` što ga je predložio Ivan Pavao II., kao i u promišljanjima njegovih nasljednika.

\section{KRATAK PRIKAZ DRUŠTVENOG STATUSA ŽENE OD ANTIKE DO DANAS}

Opće je poznata činjenica da je žena tijekom povijesti po svojem društvenom statusu bila na marginama društva. Možemo slobodno reći da je žena bila građanka drugoga reda, o čemu svjedoči i glasovita Aristotelova definicija žene (Femina est mas occasionatus) kao nepotpunog muškaraca. ${ }^{2}$ Sličan stav zastupali su i drugi ondašnji filozofi. Stoga ne čudi što je žena bila isključena iz politike, filozofije, prava, odnosno iz čitave javne sfere. Ta je diskriminacija svoj korijen prvotno imala u spolu, koji se smatrao fizički inferiornijim od muškog spola. Uz stav o fizičkoj inferiornosti utemeljenoj na različitosti spolova razvilo se i mišljenje da je žena mentalno i razumski inferiornija u odnosu na muškarca. Žene se smatraju emocionalnim bićima, nesposobnima donositi racionalne odluke. Upravo zbog takvog stava žena se nije mogla baviti političkim umijećem, koje je bilo rezervirano samo za muškarce.

Iz takvog shvaćanja žene, kao fizički i mentalno inferiorne u odnosu na muškarca, razvilo se i shvaćanje o pravnoj inferiornosti, do te mjere da ženi nisu pripadala ista prava kao muškarcu: pravo na privatno vlasništvo, pravo na obrazovanje, pravo na sudjelovanje i odlučivanje u važnim javnim događanjima. ${ }^{3}$ Stoga je njezin prostor djelovanja bio strogo omeđen kućanskim poslovima, odgojem djece te skrbi za djecu i starije ukućane.

U antičkoj filozofiji ‘usporedivost žene i muškarca nije se nažalost temeljila na 'jednakom dostojanstvu', nego, kao što smo vidjeli, na 'fiziologiji`, prema kojoj je žena po 'spolu' bila slabije biće od muškarca, što će se poslije prenijeti i na kršćansku kulturu. Na teologijskoj razini Bog je muškog roda, na ekleziologijskoj razini samo muškarci mogu biti nositelji hijerarhijske vlasti, a na socijalnoj razini žene se moraju pokoravati muževima. ${ }^{4}$ Tri su temeljna

2 Usp. Angela Ales Bello, Sul femminile. Scritti di antropologia e religione, (ur) Michaele D’Ambra, Torino, 2004., 27.

3 Usp. Marijo VOLAREVIĆ, Žena u obitelji, društvu i Crkvi. Feminizam, rodna ideologija i crkveni nauk, Glas Koncila, Zagreb, 2018., 28-29.

4 Usp. Mirjana Adamović, Žene i društvena moć, Plejada, Zagreb, 2011., 15. 
stupa u inferiornosti žene u odnosu na muškarca u kršćanstvu. Prvi je da je žena stvorena poslije muškarca, od njegova rebra (usp. Post 2,21-22); drugi je da je žena stvorena za čovjeka (muškarca) da mu bude pomoć (usp. Post 2, 18); treći je da je žena ona koja je navela muškarca na grijeh (usp. 3,12 ).${ }^{5}$ Iz takva promišljanja uvriježilo se mišljenje kako je samo muškarac savršeno ljudsko biće stvoreno na „sliku Božju“. Žena je samo posredništvom muškarca „slika Božja“ i „odsjev čovjekov“ (usp. 1 Kor 11,7). ${ }^{6}$ Negativan stav prema ženi zadržao se dugi niz godina u Crkvi.

Jedan od većih teoloških autoriteta sv. Toma razradio je cijelu teoriju o inferiornosti žene u odnosu na muškarca. Njegov teorijski nauk odražavao se gotovo do današnjih dana u Crkvi, a temeljio se u prvom redu na antičko-aristotelovsko-biološkom tumačenju čovjeka i njegove spolnosti ${ }^{7}$. Zbog toga bi bilo neopravdano samo spočitavati Crkvi činjenicu podređenosti žene muškarcu tijekom povijesti. Korijen podređenosti žene ponajprije se nalazi u krivom spolnom antropološkom tumačenju slike čovjeka istovjetno muškarca i žene koji se negativno odražavao ne samo na teologiju i filozofiju nego i na širi kulturološki, sociološki, pravni i ekonomski društveni kontekst.

Da je tome tako, svjedoči jednako civilni i crkveni zakon, prema kojima je gotovo sve do današnjih dana žena bila podređena muškarcu na temelju svoga spola. Nitko ne dovodi u pitanje zasluge u razvijanju filozofske teorije, Aristotela, Platona, sv. Tome, Kanta, Hegela, Nietzschea, Schopenhauera, Heideggera i drugih, ali se primjećuje da je njihova filozofija utemeljena na androcentričnim idejama koje svoje utemeljenje imaju u patrijarhalnoj slici svijeta. Tek J. S. Mill pokreće drugačiji društveni diskurs o ženama. ${ }^{8}$

Svi su oni zajedno kao i mnogi drugi filozofi tijekom povijesti oblikovali kodeks ponašanja za ženu preko kojeg su muškarci držali žene pod svojom kontrolom. Stoga kad govorimo o retici skrbi za sebe` kao antičkom imperativu, treba jasno istaknuti kako se ona dobrim dijelom odnosi samo na 'muškarce`, a tek manjim dijelom na 'žene`, i to u onom opsegu koji su im 'muškarci` odredili. To možemo vidjeti na primjeru Sokrata i Alkibijada. Sokrat kao mudar čovjek ima zadaću pozvati ljude da se brinu sami za sebe, za svoju dušu, radi vrlina. Tako Sokrat s jedne strane slijedi božanski zahtjev, a

5 Usp. Giovanni Battista GuzzettiI, La condizione della donna: storia e principi. Dall'inferiorita' alla reciproca complementarita' con l'uomo, Massimo, Milano 1999., 37.

$6 \quad$ Usp. Ljiljana Matković-Vlašić, Žena i Crkva, Multigraf, Zagreb 2002²., 93.

7 Usp. Isto, 92-93.

8 Usp. Mirjana Adamović, Žene i društvena moć, 16. 
s druge služi polisu; učeći građane da se brinu za sebe, za vlastiti imetak, ujedno ih uči i odgovornosti prema polisu. Sokrat daje do znanja Alkibijadu kako mladići moraju naučiti voditi skrb o svojim fizičkim, intelektualnim i moralnim sposobnostima prije nego što postanu upraviteljima polisa i voditeljima njegovih stanovnika. ${ }^{9}$

Ovdje se jasno očituje kako se društvena moć nalazi u rukama muškaraca i da se brigom za sebe oni pripremaju biti upraviteljima polisa, što žene u ono vrijeme nisu mogle ni zamisliti. Na kraju se može zaključiti kako je u antičkom etičkom imperativu brige za sebe žena mogla samo djelomično participirati, i to u onom dijelu koji joj muškarac odredi.

\section{2. ŽENINA SKRB ZA SEBE I POČETAK EMANCIPACIJE ŽENE U DRUŠTVU}

Nakon tisuća godina podređenosti žene muškarcu unutar patrijarhalnog društva koje su kreirali muškarci, u kojem se glas žene nije mogao čuti, u kojem pravno žena nije imala vlastita prava, nego je participirala djelomično na pravima muškaraca, i u kojem je bila isključena iz javnog života, krajem osamnaestog i početkom devetnaestog stoljeća žene započinju organiziraniju borbu za svoja temeljna ljudska prava. Dva su značajnija događaja utjecala na početak emancipacije žena: Francuska revolucija i industrijska revolucija. Značajna imena koja se vežu uz Francusku revoluciju i nastanak feminizma su Olympe de Gouges i Rose Lacombe, koje su, pozivajući se na temeljna ljudska prava, napisale Deklaraciju o pravima žena. Gotovo $\mathrm{u}$ isto vrijeme engleska književnica Mary Wollstonecraft napisala je jedno od svojih poznatih djela, Obrana ženskih prava. ${ }^{10}$ Stoga se u gotovo svim enciklopedijama one navode kao začetnice feminizma. ${ }^{11}$ Tada se prvi put u povijesti javlja jasnija ideja da se žene uključe aktivno u društveni život. Njihovo djelovanje u društvu ovaj put je organiziranije, i to ne samo u Francuskoj nego istodobno u SAD-u te u Engleskoj i drugim zapadnoeuropskim zemljama.

9 Franjo MIJATOVIĆ, Moralni subjekt bez (vanjskih) ograničavanja. Etički elementi u filozofiji Michela Foucaulta, 950.

10 Usp. Marijo Volarević, Žena u obitelji, društvu i Crkvi, 30.

11 Više o samom pojmu feminizma, njegovim pravcima i fazama vidjeti u djelu navedenom u prethodnoj bilješci, te u: Franco Restiaino-Adriana Cavarero, Le filozofie femministe, Paravia, Torino, 1999; Adriana Valerio, Feminismo, Nuovo Dizionario di Teologia Morale, (ur.) F. Compagnoni - G. Piana - S. Privitera (ur.), San Paolo, Milano, 1990; Anne Clifford, Feminism, u: New Chatolic Encyclopedia, vol. 5, Washington, 2003³, 671-674; Franco Restiano, Femminismo, Dizionario di filozofia, (ur.) Nicola Abbagnano, UTET, Torino ${ }^{3}$, 1998, 469. 
Drugi veliki zamah u svojoj emancipacijskoj borbi žene su dobile pojavom industrijske revolucije, tijekom koje sve više žena izlazi iz svoje privatne sfere $u$ javnu sferu, započevši s radom u industriji. Ondje su zajedno s muškarcima tražile svoja radnička prava koja su im bila ugrožena teškim uvjetima rada. Treći važan čimbenik $\mathrm{u}$ organiziranijem djelovanju žena u borbi za svoja prava bio je to sufražetski ${ }^{12}$ pokret, koji je tražio pravo glasa žena na izborima te ravnopravnost žena i muškaraca u svim područjima javnog života. Možemo slobodno zaključiti kako se emancipacijom žena u društvu žene počinju i intenzivnije ‘skrbiti o sebi', što bi bila i značajka prvog vala feminizma, istina, ne još u onom etičkom imperativu, što će se tek javiti u drugim valovima, nego više u pravnom.

No treba priznati da se u prvom valu feminizma dogodio velik pomak u pogledu 'skrbi za sebe`, jer su žene postale svjesnije sebe, svoje vrijednosti i svog dostojanstva. Ne samo da su postale svjesne nego su aktivno radile na svijesti čitavog društva, razbijajući tisućljetne tabue o ženama kao nesavršenim bićima, nepotpunom muškarcu ili djelomičnoj slici Božjoj. Smatram da su toj svijesti uz spomenute revolucije i sufražetski pokret pridonijela i dva svjetska rata, tijekom kojih je većina muškaraca bila na bojišnicama, te su žene zauzele njihovo mjesto u tvornicama i pokazale se uspješnima u obavljanju poslova koji su se do tada uglavnom smatrali muškima. Stoga i ne čudi što su mnoge zemlje nakon Prvoga svjetskog rata, a osobito nakon Drugoga, priznale pravo glasa ženama.

Nakon prvog vala feminizma ili emancipacijske faze žene se okreću novim zahtjevima. Feministkinje drugog vala ${ }^{13}$ korijen svoje podređenosti muškarcu više ne vide toliko $u$ patrijarhalnom društvu koliko u neostvarenju svojih reproduktivnih prava i majčinstvu. Njihovi zahtjevi sada su usmjereni na pravo abortusa, kontracepcije, razvoda, prepoznavanja homoseksualnosti. ${ }^{14}$ Začetnicama drugoga vala feminizma smatraju se Simone de Beauvoir s djelom Drugi spol i Betty Frieden s djelom Mistika žene; ova potonja Amerikanku srednje klase opisuje kao zatočenicu obitelji i obiteljskih poslova bez ikakve perspektive u budućnosti vezane za ostvarenje društvene karijere.

Simone de Beauvoir egzistencijalističkim je filozofskim promišljanjima ucrtala put drugom valu feminizma. U djelu Drugi spol

12 Potječe od engleske riječi suffrage, što znači pravo na glas.

13 Više o drugom valu feminizma vidjeti u: Franco Restiaino-Adriana Cavarero, Le filozofie femministe; Marijo Volarević, Žena u obitelji društvu i Crkvi, 87-93.

14 Usp. Karen Lebacoz, Feminism, EBio, vol. 2, ur. W.T. Reich-Shuster Macmillan, New York, 1995., 809-810. 
napisala je svoju čuvenu rečenicu: „Ženom se ne rađa, nego postaje“, ${ }^{15}$ čime je otvorila put razlikovanju roda i spola. Prema takvoj teoriji ne postoji nekakva biološka razlika između muškarca i žene. Ženskost i muškost bili bi samo proizvod kulture i društvenog okruženja. Drugim riječima, žena i muškarac ne razlikuju se biološki, nego se razlikuju po nametnutim pravilima društvenog ponašanja točno određenim za muškarca i ženu. A to onda znači da svatko od njih može birati da bude muško ili žensko, neovisno o biološkom spolu, što će poslije otvoriti put rodnoj ideologiji. ${ }^{16}$

Možemo reći da je Simone de Beauvoir preko tri polazne točke usmjerila razvoj drugog vala feminizma pa poslije i nastanka rodne ideologije. Prva je da ne postoji temeljna razlika između muškarca i žene koju je nemoguće nadići zbog njihova spola. Spolna razlika za nju je osnova za svaku kasniju razliku vrednovanja i raščlambe hijerarhijskog sustava moći. Druga točka vezana je za društvo, povijest i kulturu, koji zapravo i jesu ovu spolnu razliku učinili takvom. Žena je zapravo skup dodijeljenih društveno nametnutih i stečenih odlika u koje se svaka žena s većim ili manjim uspjehom uklapa. Treća točka vezana je za sustav vrijednosti u kojem ženska i muška bića (spol) postaju muškarci i žene (rod). ${ }^{17}$

Početkom 80-ih godina 20. st. javlja se i treći val feminizma, koji još zovemo i postfeminizmom, koji pod utjecajem postmoderne donosi sasvim drugačiju sliku žene. Postfeminizam još u drugom valu ne samo da propituje koja je razlika između muškarca i žene nego i koja je razlika između samih žena. Napušta se model jedinstvenog feminizma. ${ }^{18}$ Feministkinje trećeg vala smatraju da ne postoji žena ut sic kao takva, nego da postoje različite kategorije žene, s različitom poviješću, zbog čega i postoje različita objašnjenja njihove podređenosti. ${ }^{19} \mathrm{O}$ tom problemu progovara Bell Hooks u svojoj knjizi Zar ja nisam žena. U trećem valu feminizma sve su brojniji prigovori crnih feministkinja, koje ističu kako je nemoguće govoriti o istoj ženi, odnosno istim iskustvima svih žena tijekom povijesti kad s jedne strane stoje ropkinje, a s druge robovlasnice. Zbog toga

15 Simone de Beauvoir, Il secondo sesso, Saggiatore, Milano, 2008., 271.

16 Usp. Silvio Botero Giraldo, Una nuova morale matrimoniale, Logos, Roma, 2007., 28.

17 Usp. Adriana Zaharijević, Kratka historija sporova: Šta je feminizam?, u: Netko je rekao feminizam, 384; u: https://pescanik.net/wp-content/PDF/10adriana. pdf (preuzeto 27. 2. 2021.).

18 Postfeministkinje smatraju da ne postoji „kategorija žene“ kao takve kao čvrstog objekta, nego „kategorija ženā“, koje mogu biti: crnkinje, bjelkinje, žute, lezbijke, heteroseksualne... Usp. Marijo Volarević, Žena u obitelji, društvu i Crkvi, 93-94.

19 Usp. Gaia Marsico, Bioetica: voci di Donne, Dehoniane, Bologna, 2002., 88-89. 
one smatraju da se mora odustati od iluzije da postoji jedinstveni identitet žene'.

Iz takvog promišljanja može se zaključiti kako pojedini feministički pokreti nisu uvijek vodili brigu i skrb za svaku ženu podjednako, nego da su unutar tih pokreta postojali i osobni interesi, koji su često isključivali neku od kategorija žena. Tako su lezbijke imale svoj pokret, poznat pod nazivom ‘ružičasta napast) (lavander menace), i prigovarale da ih heteroseksualne žene ne mogu zastupati. ${ }^{20}$ Sve to dovelo je do fragmentacije feminizma kao jedinstvenog pokreta, jer ako nema jedinstvene kategorije žene, onda ne može biti ni jedinstvene platforme $\mathrm{u}$ borbi za ostvarenja ženinih prava, a samim time nema ni mogućnosti za kreiranje jedinstvene etike žene. Ipak, upravo u vrijeme postfeminizma pojedine feministkinje pokušale su na teorijskoj razini dokazati jedinstveni etički imperativ za sve žene, a to je «skrb ili briga za druge».

\section{FEMINISTIČKA ETIKA ILI ETIKA ŽENE}

Opće je poznata činjenica da se feminizam, osim što je podijeljen u tri povijesna razdoblja ili vala (neki tvrde da ih danas postoji već pet), također dijeli na tri glavna feministička pravca, iz kojih su se onda razvili postfeministički pravci. To su: liberalni, socijalni i radikalni feminizam, kao temelj postfeminističkim pravcima, poput: lezbijskog, crnog, rodnog, ekološkog itd. Stoga se i nameće logično pitanje: ako postoji više feminističkih pravaca, je li moguće kreirati jednu zajedničku feminističku etiku? Mnogo je govora među feministkinjama zadnjih nekoliko desetljeća o 'feminističkoj etici' i tome što bi ona bila. ${ }^{21}$ Feministkinje poput Alison Jaggar, Rosemarie Tong, Farley Margaret te mnoge druge nastojale su odgovoriti na pitanje što bi to bila feministička etika i koje su njezine glavne točke. Feministička etika nastala je najprije na području SAD-a i zatim se proširila u ostalim zapadnim zemljama. Feministkinje su smatrale kako s patrijarhalnim naslijeđem treba raskinuti ne samo na društvenom i političkom području nego i na moralno-etičkom, u kojem su se stvorile konvencionalne vrijednosti i etičke teorije koje podupiru podređenost žene muškarcu. Stoga je, kako bi se stvorila feministička

20 Usp. Marijo Volarević, Žena u obitelji, društvu i Crkvi, 94-95.

21 Više o „feminističkoj etici“ vidjeti u: Alison Jaggar, „Feminist ethics“, Encyclopedia of Ethics, ur: Lawrence C. Becker - Charlotte B. Becker, Vol. I, Routledge, New York., 2001², 528-539; Daryl Koehen, Rethinking feminist ethics: care, trust and emphaty, Routledge, London - New York, 1998; Margaret Urban Walker, Moral Understandings. A feminist Study in Ethics, Routledge, New Jork - London, 2003. 
etika, u prvom redu potrebno pronaći korijen podređenosti žene na području etike. Tako su primjerice feministkinje drugog vala uzrok podređenosti žene vidjele ne toliko u društvenim strukturama koliko u biološkim čimbenicima, tj. u majčinstvu. Zbog toga su nastojale uvesti nove moralno-etičke vrijednosti, dotad nezamislive, poput prava na abortus, reproduktivnih prava, prava na kontracepciju itd.

Alison Jaggar u svojoj analizi iznosi pet uzroka podređenosti žene, od kojih je jedan upravo s područja etike, ${ }^{22}$ čije su norme uglavnom konstruirali muškarci prema svojoj potrebi, ne vodeći računa o ženama. Činilo se da će rješavanjem ovih problema biti lakše kreirati novu etiku, u kojoj bi žene imale veću važnost i ulogu. Pokazalo se ipak, kao što smo već spomenuli, da u feminističkom svijetu ne postoji jedinstven pogled na etiku, kao ni na uzroke podređenosti žene u društvu. Taj se problem u svoj svojoj oštrini javio u trećem feminističkom valu, koji pod utjecajem postmoderne nije imao jedinstven odgovor na pitanje tko bi i što bio ‘subjekt žena'. Naravno da se to onda odrazilo na etičkom području. Tako liberalne feministkinje podređenost vide u uskraćivanju ženskih prava i društvenim strukturama koje to dopuštaju, socijalne feministkinje u ekonomskoj i socijalnoj nejednakosti žena i muškaraca, radikalne feministkinje u manjku autonomije žena na području politike, gospodarstva, seksualnosti, roda, spola itd. ${ }^{23}$

To nam samo potvrđuje da različite teorije feminističke etike još uvijek nemaju jasno definirane postavke kako i na koji način univerzalno djelovati na području etike. ${ }^{24}$ Sve to nam otkriva kako 'feministička etika' na prvome mjestu traži način kako riješiti problem moći i muške dominacije nad ženama, a tek usputno se bavi pitanjem dobra i zla. U tom surječju pojedine feministkinje, poput Daryl Koehen, predlažu treći put, koji bi bio zajednički svakoj ffeminističkoj eticis, a to je retika žena) ${ }^{25}$ Danas se u feminističkom svijetu ta razlika sve više prihvaća. ${ }^{26}$ Imajući to u vidu, u sljedećem podnaslovu progovorit ćemo upravo o tome koja bi se to i kakva etika mogla, prema pojedinim feministkinjama, vezati uz retiku žene,, kao nešto njoj svojstveno i zajedničko svim ženama.

22 Usp. Alison Jaggar, Feminist ethics, 528.

23 Usp. Margaret A. Farley, Feminist ethics, A New Dictionary of Christian Ethics, James F. Childress-Johan Maquarrie (ur.), SCM, London, 1986., 229.

24 Usp. Rosemarie Tong, Feminist ethics, u Encyclopedis of Applied Ethics, vol. 2, Ruth Chadwick (ur.), Academic Press, San Diego, 1998., 229.

25 Usp. Daryl Koehn, Rethinking feminist ethics: care, trust and emphaty, 5.

26 Usp. Adelaide Conti, L'approcio feminile nell'eticadella cura. Spunti di riflessione, La famiglia 34 (2000.), 203, 49. 


\section{BRIGA ZA DRUGOG KAO ETIČKI IMPERATIV}

Pojedine feministkinje trećeg vala prihvaćaju biološku razliku između muškarca i žene. Štoviše, smatraju da bi biološka razlika između muškarca i žene mogla biti temelj za konstruiranje zasebne ‘ženske etike`. Carol Gilligan prva je nastojala dokazati kako žene imaju drugačiji pristup shvaćanju morala od muškaraca. U tom pravcu svoje istraživanje započinje opservacijom kako su proučavatelji morala poput Kholberga, Piageta i Eriksona većim djelom preko svojih studija razvili teoriju da su žene 'moralno inferiornije` u odnosu na muškarce. Takvu tradicionalnu moralnu perspektivu koju nalazimo u klasičnim tekstovima o etici, Gilligan definira kao etiku iz 'perspektive pravednosti koja se veže uz muškarce i koja bi bila temelj tzv. ‘muške etike`. Gilgan takvoj etici suprotstavlja jednu drugačiju perspektivu, a to je perspektiva 'voditi brigu o' ili 'odgovorna briga', o kojoj se nije vodilo dovoljno računa tijekom povijesti, jer se vezala isključivo za žene, koje su bile isključenje iz etičkih promišljanja. ${ }^{27}$

Gilligan započinje raspravu o hipotezi Heinzove moralne dileme i dokazuje kako rezultati istraživanja Lawrencea Kholberga nisu točni, jer su oni koji su sudjelovali u istraživanju bili većinom muškarci. Heinzova dilema je kontraverzna moralna dilema u kojoj se Heinz našao kad je njegova supruga nasmrt bolovala od karcinoma. Postojao je lijek koji ju je mogao spasiti, ali on nije imao dovoljno novca da ga kupi. Zbog toga se našao u dilemi da li da ga ukrade ili da pusti da mu žena umre. Ovaj problem Gilligan je izložila dječaku Jakeu i djevojčici Amy. Amy se u svojem odgovoru pokazala nesigurnom, zabrinutom za posljedice, dok je Jake bio jasniji i sigurniji. Gilligan objašnjava to time što je Amy bila zabrinuta za Heinza i njegovu ženu. Djevojčica je razmišljala o tome da bi Hainza, ukrade li skupi lijek, mogli uhititi i tko će onda voditi brigu o njegovoj ženi, kojoj je, s druge strane, trebalo spasiti život. U prosudbi djevojčice osjetila se određena nesigurnost, dok je dječak bio izričito protiv, bez veće sumnje $u$ ispravnost svoje odluke. ${ }^{28}$ Gilligan na temelju njihovih odgovora dolazi do zaključka kako postoji razlika između muškaraca i žena na području etike, odnosno pri donošenju pojedinih moralnih prosudba. ${ }^{29}$

27 Usp. Gaia Marsico, Bioetica voci di donne, 42.

28 Usp. Marijo Volarević, Žena u obitelji, društvu i Crkvi, 177.

29 Usp. Carol Gilligan, In a different voice: psycological theory and women's development, Harvard University Press, Cambridge, 1982., 27-38. 
Gilligan nadalje zaključuje da je stav ‘brinuti se o’ drugima bliži ženama, zajedno s kompetencijama moralnim i emocionalnim. One prije izabiru 'etiku odgovornosti, a tek potom 'etiku pravednosti, koju većinom izabiru muškarci. ${ }^{30}$

Slično promišlja i Nel Noddings u svojoj knjizi Caring: A feminine Approch to Etchis and Moral Education. Sara Ruddick, Virgina Held, Nancy Chodorow otišle su i korak dalje, smatrajući da žene imaju posebnu etiku, različitu od muškarca, koja svoj korijen ima u majčinstvu. Upravo iz takve etike razvila se, po njihovu mišljenju, etika brige za drugog. One su nastojale na neki način uvesti žensku dimenziju u moral, tj. djelomično ga feminizirati upravo preko etike koja svoj korijen ima u majčinstvu. ${ }^{31} \mathrm{Za}$ razliku od feministkinja drugog vala koje su u majčinstvu vidjele podređenost žene muškarcu, Sara Ruddick i Nancy Chodorow vidjele su potencijalnu superiornost žene $u$ odnosu na muškarca na području etike. Ruddick svoju teoriju potkrepljuje činjenicom da se majčinskim razmišljanjem' i 'majčinskom praksom' u svakodnevici, kojom majka štiti, podiže i uči svoju djecu, razvijaju etičke vrijednosti koje su istodobno racionalne i emocionalne, kognitivne i afektivne. Stoga zaključuje da su ove vrijednosti koje proizlaze iz ‘majčinske prakse` i ‘majčinskog promišljanja' ujedno vrijednosti za sve ljude u društvu, podjednako za žene i muškarce. ${ }^{32}$

Na kraju možemo zaključiti kako je ‘etika brige za drugog` koja svoj korijen ima u 'majčinstvu' glavni razlog zašto ženski univerzum više vodi računa o osobi i odnosima među osobama, a manje o pravu i pravednosti. 'Etika brige za drugog' ukorijenjena u 'majčinstvu' pokazuje se kao glavni ključ koji može otvoriti vrata drugačijem stilu ponašanja, u kojem u etičkim prosudbama i ponašanjima i osjećaj igra važnu ulogu, a ne samo racionalna prosudba, u kojem se međuljudski odnosi ne vežu samo uz ispunjenje ugovornog djela i prava, nego uz besplatnost i skrbi za drugog. Na taj način od iskrbi za sebe što znači prepoznati dostojanstvo i ljepotu biti čovjek istovjetno muškarac i žena. Svoju odgovornost, sposobnost i granice, fizičke i intelektualne, žena i muškarac, trebaju preuzeti brigu za drugoga, a to znači u prvom redu vrednovati svoju različitost kao

$30 \quad$ Usp. Isto, 166.

31 Više o tome vidjeti u: Sara Ruddick, Maternal Thonking: Toward a Politics of Peace, Bacon, Boston, 1989; Nel Noddings, „Caring: A feminine Approch to Etchis and Moral Education, University of California Presss, Berkely, 1984; Nancy Chodorow, The reproduction of mothering. Psyhoanalyisis and sociology og gender, University of California Press, Berkeley, 1978.

32 Usp. Sara Ruddick, Il pensiero materno, Red, Como, 1993., 29-41. 
dar i bogatstvo, odakle se rađa zahtjev za ulaganje vlastite energije, fizičke, emocionalne, intelektualne u to da se (skrbeći za sebe), istodobno 'skrbim i za drugog. ${ }^{33} \mathrm{Na}$ tragu takve etike svakako je i ‘novi feminizam» Ivana Pavla II.

\section{NOVI FEMINIZAM I ETIKA BRIGE ZA DRUGOG}

Tom gorućem društvenom problemu statusa žene u društvu, njezina dostojanstva, njezine važnosti za obitelj, društvo i Crkvu od svih naučitelja Katoličke Crkve najviše je vremena i pozornosti bez sumnje posvetio Ivan Pavao II. U mnogim svojim tekstovima upozoravao je na nepravde nanesene ženama, bio je prvi papa koji se ispričao za sve nepravde koje je Crkva tijekom povijesti nanijela ženama. Svojim djelovanjem i pisanjem otvorio je unutar Crkve jedan sasvim nov pogled na ulogu i važnost žene kako za Crkvu tako i za društvo. Nastojao je otvoriti dijalog i s najradikalnijim feminističkim krugovima, štoviše, i sam je predložio 'novi feminizam' kao mogući put prema ostvarenju ženinih prava i njezinom većem doprinosu društvu i Crkvi. Kako kaže Marisa Orecchia za Ivana Pavla II., „on ne izbjegava koristiti termin feminizam: nego slobodom djece Božje ulazi u ovu riječ, ovu realnost, kao Krist, mijenja je iznutra i čini je novom“. ${ }^{34}$

Upravo na tom tragu, kako bi obnovio sliku žene, Ivan Pavao II. u apostolskom se pismu Mulieris dignitatem vraća na početak, poziva se na Krista i na njegov stav prema ženama, nastojeći ispraviti nepravde nanesene ženama tijekom povijesti. ${ }^{35}$ Jer i najradikalnije feministkinje nisu mogle pronaći nikakvu zamjerku Kristovu ponašanju i ophođenju prema ženama, osobito kad se zna povijesni i kulturološki kontekst njegova doba. Kristovo ponašanje prema ženama bilo je za ono vrijeme revolucionarno, za pripadnike vjerske elite sablažnjivo. Svjestan je toga bio Ivan Pavao II. te zato stvari vraća na početak i veže ih uz Krista. ${ }^{36}$ Upravo Kristovim očima Ivan Pavao II. gleda na riječ feminizam.

U tom suglasju Ivan Pavao II. predlaže 'novi feminizam', preko kojeg bi žena trebala djelovati u Crkvi, društvu i obitelji. Termin ‘novi

33 Usp. Enrica Rosanna, Donne per il terzo millennio. Problema o risorsa?, Milella, Lecce, 2007., 131.

34 Marisa Orecchia, u: http://www.federvitapiemonte.it/html/nav_Marisa_ Orecchia_-_Per_un_nuovo_femminismo.php (16. 3. 2021.).

35 Usp. Ivan Pavao II., Mulieris dignitatem. Apostolsko pismo o dostojanstvu i pozivu žene prigodom Marijanske godine, Kršćanska Sadašnjost, Zagreb, 2003³., br. 12 (dalje: $M D$ ).

36 Usp. Isto, 
feminizam spominje samo tri puta, a najbolje ga opisuje u enciklici Evagelium Vitae, naglašavajući kako „u kulturalnom zaokretu u korist života žene imaju jedinstven i možda odlučujući prostor misli i djelovanja: na njima je red da postanu promicateljice novog feminizma', koji, bez padanja u napast da se posluži 'muškaračkim) modelima, zna prepoznati i izraziti istinski ženski genij u svim očitovanjima društvenog života, djelujući na korist nadilaženja svakog oblika diskriminacije, nasilja i iskorištavanja“.37 U ovom kratkom, ali sadržajno bogatom tekstu može se nazreti što bi to bio ‘novi feminizam ı kakva bi etika trebala proizaći iz njega. Prvo što možemo primijetiti jest da Ivan Pavao II. ne razmišlja o novom feminizmu samo kao o nekoj teoriji nego ga vidi i u praksi: „u kulturalnom zaokretu u korist života (žene) imaju jedinstven i možda odlučujući prostor misli i djelovanja“. ${ }^{38}$ Drugo je da zna prepoznati i izraziti istinski ‘ženski genij’ u svim očitovanjima društvenog života. Stoga, da bi se shvatio novi feminizam, potrebno je odgonetnuti što je to ‘ženski genij' za Ivana Pavla II. ${ }^{39}$

Iz njegovih tekstova u kojima govori o 'ženinu geniju', može se zaključiti sljedeće: Ivan Pavao II. ‘ženin genij’ veže uz samu narav žene, u kojem se očituje crta Božjeg plana sa ženom. ${ }^{40}$ Nadalje, 'genij žene` prema Ivanu Pavlu II. ima neke svoje specifičnosti, a to su prije svega: „osjetljivost za čovjeka, zbog toga što je čovjek“, ${ }^{41}$ iz čega onda proizlazi i otvorenost životu, ${ }^{42}$ postojanost u sposobnosti shvaćanja stvarnih društvenih poteškoća i suočavanja s njima. ${ }^{43} \mathrm{Iz}$ dosad rečenog 'genij žene` možemo definirati kao: „neotuđivu vrijednost ženstvenosti, njezinog načina postojanja i odnosa sa svijetom“ ili „kao bitnu stvarnost koja pripada ženi, kao njezino stanje - habi-

37 Ivan Pavao II., Evangelium vitae - Evanđelje života, Kršćanska sadašnjost, Zagreb, 2003․, br. 99. (dalje: EV).

38 Isto.

39 Više o ženinu geniju vidjeti u: Marijo Volarević, Društveno-etički značaj 'genija žene' i njegove temeljne karakteristike, Bogoslovska smotra, 83 (2013.) 1, 75-89.

40 Ivan Pavao II., Pismo ženama, br. 10.

41 Ivan Pavao II., MD, br. 30.

42 Usp. Ivan Pavao II., Senza il contributo delle donne la società è meno viva, la cultura meno ricca, la pace più insicura (23. VII. 1995.), Insegnamenti di Dovanni Paolo II, Città del Vaticano, 1998., 123-124.

43 Slobodno vrijeme, kvaliteta života, migracije, socijalne službe, eutanazija, droga, zdravlje i pomoć, ekologija itd. U svim tim područjima pokazat će se dragocjenom nazočnost žena, koje će pridonijeti uništavanju proturječnosti društva sazdanog isključivo na kriterijima učinkovitosti i produktivnosti. Usp. Ivan Pavao II., Piena valorizzazione del ruolo della donna nell'ambito dell'economia e del lavoro (20. VIII. 1995.), Insegnamenti di Govanni Paolo II, Città del Vaticano, 1998., 228-229. 
tus, kojim ona izražava svoj način djelovanja, svoje biti žena, sa svijetom i s drugima u svakodnevici“. ${ }^{4}$

I nasljednici Ivana Pavla II. Benedikt XVI. i papa Franjo promiču 'genij žene', uvidjevši njegovo bogatstvo za društvo i Crkvu, i to ne samo u sporednim djelatnostima nego i na svim ključnim društvenim razinama. ${ }^{45}$ Jer ovakav opis 'genija žene' lako bi se mogao protumačiti kao nešto marginalno i sporedno za društvo, ${ }^{46}$ istina, korisno društvu, ali nešto što se u prvom redu veže samo uz žene kao emotivna bića, a manje uz muškarce, kao racionalna bića sposobna preuzeti ‘odgovornost za drugog`, dok bi žena bila sposobnija preuzeti ‘brigu za drugog’. Novi feminizam što ga predlaže Ivan Pavao II., a prihvaćaju njegovi nasljednici, razbija ovu etičku ‘dihotomiju». Etika koja proizlazi iz 'novog feminizma', a odvija se preko 'genija žene’ kao njoj svojstvena talenta utoliko što je žena, pokazuje se dosta bliska etici 'skrbi za drugog'. Naravno, etika i poziv od skrbi za sebe do skrbi za drugog nije upućena samo ženama nego svakom čovjeku, podjednako ženi i muškarcu. ‘Etika skrbi za drugog` i etika koja proizlazi iz 'novog feminizma) zapravo je poziv i apel preko kojeg treba dokinuti 'unilateralnu' etiku u kojoj je samo muškarac bio nositeljem i gospodarom takve etike, izgrađene na kulturološkim stereotipima. Etika koja proizlazi iz 'novog feminizma temelji se na novom etičkom imperativu, tj. izgradnji ‘dvoglasne recipročne kulture ${ }^{47}$ zajedništva, obogaćene po naravi različitosti čovjeka biti muškarac i biti žena, $\mathrm{s}$ istim dostojanstvom, istim pravima, ali bez napasti upadanja $\mathrm{u}$ 'muškaračke` modele. ${ }^{48}$ Naprotiv, žena i muškarac po svojoj istovjetnoj ljudskoj naravi i dostojanstvu u bogatstvu svoje ontološke različitosti biti muško i biti žensko kao jednakopravni partneri pozvani su aktivno djelovati u svim društvenim porama u svoj svojoj istovjetnosti i različitosti.

\section{ZAKLJUČAK}

iako žene zadnjih nekoliko desetljeća posjeduju ista prava kao i muškarci, vidljivo je da su i dalje diskriminirane, unatoč svim naporima da se probudi društvena svijest o njihovoj jednakosti i ravno-

44 Marijo Volarević, Žena u obitelji, društvu i Crkvi. Feminizam, rodna ideologija $i$ nauk Crkve, 202.

45 Usp. Benedikt XVI., Discorso al congreso sul ruolo delle done nella promozione dei diritti umani, L'oservatore Romano, 22. III. 2009, 8; Papa Franjo, Evangelii gaudium- Radost Evanđelja, Kršćanska sadašnjost, Zagreb, 2013, br. 103.

46 Usp. Enrica Rosanna, Donne per il terzo millennio, 86.

47 Usp. Isto, 46.

48 Usp. Ivan Pavao II., EV, br. 99. 
pravnosti u društvu. Građenje svijesti o jednakopravnosti žene i muškarca započelo je pojavom feminističkog pokreta krajem osamnaestog stoljeća. Feministički pokret je, osobito u svojem prvom emancipacijskom valu, otvorio prostor ženama da započnu same 'skrbiti o sebi', budući da su tijekom čitave ljudske povijesti, pa tako i u antici, skrb za žene vodili muškarci umjesto njih. Antički imperativ 'skrbi za sebe` vrijedio je za žene u onolikoj mjeri u kojoj su muškarci smatrali da odgovara etičkim i duhovnim sposobnostima žene. Vrline poput hrabrosti, pravednosti, jakosti itd. smatrale su se svojstvenima jedino muškarcima i za žene su bile nedostižne, budući da ih se smatralo 'nepotpunim čovjekom', s umanjenim racionalnim sposobnostima, koje se vode isključivo emocionalnošću, zbog čega nisu mogle participirati ni u kakvim značajnijim društvenim djelatnostima.

Čitavo društvo, njegova kultura, filozofija, moral, bilo je ‘unilateralno', tj. kreirano i stvoreno od muškarca, prema njegovoj mjeri i potrebi. Pojavom feminizma žene nastoje pokazati da su jednako sposobne kao i muškarci, da mogu obavljati iste poslove kvalitetno kao i muškarci, zbog čega su se nastojale prilagoditi ‘muškaračkim modelima' u društvu, kulturi, etici itd. U takvoj igri počele su nesvjesno gubiti svoj identitet različitosti biti čovjek istovjetno muškarac i žena. Drugim riječima, samo su se prikvačile za ‘unilateralnu kulturu koju su već kreirali muškarci i nastojale se prilagoditi. Upravo to je jedan od glavnih razloga zašto su žene unatoč jednakim pravima i dalje diskriminirane.

U pluralizmu feminističkih pokreta u njihovom trećem valu javlja se i pokret koji se temelji na različitosti, te sve ono što se smatralo slabošću, a pripisivalo se uglavnom ženama, poput emocionalnosti, ‘skrbi za drugog’, majčinstva, shvaća kao snagu žene, pa čak i kao nadmoć nad muškarcima. Isti takav pogled ima i ‘novi feminizam». Postaje sve očitije da pitanje diskriminacije žene nije samo pravno i ekonomsko nego etičko i kulturološko. Ono zahtijeva promjenu društvene svijesti, u kojoj se različitost doživljava kao dar. To znači da različitost žene od muškarca i priznavanje njezinih urođenih sposobnosti nije slabost, nego dar. Da bi se uklonila diskriminacija žene, potrebno je u društvu stvoriti recipročnu 'dvoglasnu kulturu ' unutar koje bi se vrednovala različitost između muškarca i žene, gdje bi muške sposobnosti koje posjeduje žena i ženske sposobnosti koje posjeduje muškarac samo na drugačiji način, neometano mogle doći do izražaje i gdje se muškarac i žena ne bi doživljavali kao protivnici, nego kao jednakopravni partneri sa svim svojim urođenim sposobnostima biti čovjek istovjetno muškarac i žena. 
WOMAN FROM THE ANCIENT IMPERATIVE OF "SELF-CARE" TO THE ETHICAL IMPERATIVE OF “CARE FOR THE OTHER”: A FEMINIST AND CHRISTIAN VIEW

\section{Summary}

By ethical examination of "self-care" and "care for the other" the author deals with the issue of woman's status, her importance and her ethical contribution to society. In the first part, starting from the ancient imperative of "self-care", we talk about the historical subordination of woman and the position of woman in society, which clearly shows how the ancient imperative of "self-care" was valid to the extent that men allowed them, since in a patriarchal society created by men all social power was in their hands. It is only with the emergence of feminism and the emancipation of women in society, which is discussed in the second part of the paper, that woman gets her own space to be able to "care for herself". In this context, only then the ancient imperative of "self-care" proves to be an ethical imperative for everyone, man and woman alike, that is, woman becomes an equal partner to man, which belongs to her in the dignity of a human person - to be a human being.

The third part of the paper discusses the ethical imperative related to women and their rights, as well as their diversity in relation to men. This difference is also evident in the ethical field, so one of the basic questions is what kind of ethics women represent and whether there are differences between the ethics of men and women. Whether this ethic is linked to feminist ethics or to ethics based on the specifics of being a woman, is the fundamental aim of this paper's research. In this context, we can say that one of the ethics based on the dignity of being a woman is the "ethics of caring for the other", which is discussed in the fourth part of the paper. This "ethics of caring for the other" is rather similar to the ethics arising from the "new feminism" of John Paul II, which the author discusses in the fifth part, where he concludes that the task of new feminism would be to create a "two-voiced culture" in which woman and man stand as equal partners in their identity but also in diversity, perceiving each other as a gift and an enrichment.

Keywords: ancient times, "self-care", woman, man, feminist ethics, ethics of caring for the other, feminism, new feminism. 